\title{
George Karpati (1934-2009)
}

George Karpati, the Isaac Walton Killam Professor of Neurology at McGill University and a world renowned specialist in neuromuscular disorders died suddenly on February 6, 2009 during a working dinner at the McGill Faculty Club.

He was born in Debrecen in North Eastern Hungary and towards the end of the second world war he was deported with his parents to one of the infamous work camps to which Hungarian Jews were then sent. His father was sent further to the extermination camp at Bergen Belsen. George never talked about his early life, except on the insistence of his sons.

He left Hungary with his mother at the time of the Hungarian revolution in 1956. He completed his medical education at Dalhousie University and then joined the Montreal Neurological Hospital. He did postgraduate work with King Engel at the NIH and returned to the MNI as an Assistant Professor in 1967. George Karpati had a boundless curiosity and fascination with scientific investigation. He was very widely read, an excellent diagnostician and a superb teacher. Muscle pathology was his overwhelming passion, which led to the publication of an authoritative text written with Stirling Carpenter, his partner in the study of muscle diseases and his friend. With the neurochemist Leon Wolfe, Stirling Carpenter, the geneticist Eva Andermann and the senior author of this obituary, he studied a panoply of progressive neurological disorders, including the cerebral lipidoses, white matter disorders and storage diseases.

He established a neuromuscular research group at the MNI to tackle the biology of neuromuscular diseases from different perspectives and recruited outstanding people in their respective field of cell biology (Heather Durham, Josephine Nalbantoglu), biochemistry (Paul Holland), molecular biology (Ken Hastings), physiology (Basil Petrof, Tanja Taivassalo), genetics (Renald Gilbert), mitochondrial diseases (Eric Shoubridge) and neuromuscular neurology (Daniel Gendron, Angela Genge), rendering the MNI one of North America's foremost centers for neuromuscular medicine.

He was one of the first to describe now well recognized neuromuscular entities such as inclusion body myositis, polyglucosan body disease, giant axonal neuropathy, adult onset acid maltase deficiency, myosin depletion myopathy and has contributed in a significant way to the understanding of their underlying pathophysiology.

He discovered the surface plasma membrane localization of dystrophin, the defective gene product in Duchenne Muscular Dystrophy. This discovery was an important step in the design of therapeutic strategies for muscular dystrophies, to which he devoted much of his career with pioneering work in myoblast transfer, stem cell therapy, viral mediated gene transfer and upregulation strategies for homologous proteins.

He had numerous disciples, who eventually went on to distinguished careers in the field of muscle pathology, neuromuscular neurology and genetics. (Calvin Melmed, Guy Rouleau, Agnes Jani, Joseph Jossiphov, Bassem Yamut, Jordi Casademont, Morris Danon, Boaz Weller, Johnny Huard, Gyula Acsadi, Giovanna Pari, Michel Melanson, Maria Molnar, Rita Horvath, Hanns Lochmuller, Wendy Johnston, Michelle Mezei, Antal Szabo, Dubravka Dodig, Amelie Nadeau, Erin O'Ferrall, amongst many).

He was happily married to Shira Tannor and they had two sons Adam and Joshua to whom he was extremely devoted. George Karpati was actively involved in the medical and scientific life of the Montreal Neurological Hospital and Institute and the University. His expertise was widely recognized.

He was an Officer of the Order of Canada and a Chevalier of the Order of Quebec. He was a fellow of the Royal Society of Canada and received the Wilder Penfield Award of the government of Quebec, the Governor General's anniversary medal, the distinguished scientist award from the Canadian Society of Clinical Investigation, Lifetime Achievement Awards from the Muscular Dystrophy Association Canada, World Federation of Neurology and the Montreal Neurological Institute, as well as honorary doctoral degrees from the Universities of Marseilles and of Debrecen. He was an honorary member of the Hungarian Academy of sciences and of the American Neurological Association.

His death is a heavy loss to our entire community and to the world of muscle research.

Michael Sinnreich, Frederick Andermann Montreal, Quebec 